\author{
JACEK RUDEWICZ \\ Uniwersytet Szczeciński, Polska \\ University of Szczecin, Poland
}

\title{
Przeobrażenia przestrzenno-funkcjonalne terenów poportowych w Szczecinie w świetle klasycznych modeli miasto-port
}

\section{Spatial and functional transformations of post-port areas in Szczecin (Poland) in the context of classical city-port models}

\begin{abstract}
Streszczenie: Głównym celem artykułu jest porównanie zagadnień teoretycznych obecnych w literaturze naukowej w postaci modeli przestrzenno-funkcjonalnych obszarów miejskich i portowych z obserwowanymi zależnościami tych obszarów w portowym mieście Szczecin. W artykule zaprezentowano i zestawiono ze sobą modele stworzone przez geografów i urbanistów badających ewolucję układów miasto-port morski w kontekście zmieniających się trendów światowych w technice i ekonomice transportu morskiego. Artykuł zawiera odniesienia do tzw. strefy interface, obszaru stykowego miasta i portu, który wobec dążeń miast do rewitalizacji przestrzeni staje się strefą o dużym potencjale inwestycyjnym. Przykładem wykorzystania takich możliwości są np. Rotterdam, Hamburg, Kopenhaga, Baltimore, Gdańsk i podobne wielkością do Szczecina - Bilbao. Sukcesy tych miast przekonują, że wysiłek rewitalizacji i pracy koncepcyjnej przynosi im duże korzyści wizerunkowe, gospodarcze i społeczne. Stało się to dzięki stworzeniu atrakcyjnych terenów nadwodnych (waterfront). W artykule dokonano analizy rozwoju relacji miasta Szczecin i będącym jego „genetycznym kodem" terenami portowymi oraz przemysłowymi wraz ze szkicem przyszłych zamierzeń i planów włodarzy miasta wobec odzyskanych terenów portowych.
\end{abstract}

\begin{abstract}
The purpose of this paper is to confront the theoretical issues present in the academic literature in the form of spatial-functional models for urban and port areas with the observed relationships for these areas based on the example of a selected city in Poland. The article addresses the issues of universality of models created by geographers and urban planners studying the evolution of city/port systems in the context of changing global trends in technology, economics and scale of maritime transport. The article describes the interface zone, the area where the city and the port meet, which in the current economic conditions and aspirations of contemporary cities to revitalise their space is turning into a zone with great potential. Examples of such opportunities include Rotterdam, Hamburg, Copenhagen, Baltimore, Gdańsk and, similar in size to Szczecin, the city of Bilbao. The success of these cities shows that the effort of revitalisation brings them great branding benefits. The article contains a description of the development of relations between the city of Szczecin and its "genetic code" of port and industrial areas, together with an outline of the city's future intentions and plans for the inherited port areas.
\end{abstract}

Słowa kluczowe: miasta portowe; planowanie przestrzenne; port; tereny poprzemysłowe Keywords: brownfields; port; port cities; urban planning; waterfronts 
Otrzymano: 11 sierpnia 2021

Received: 11 August 2021

Zaakceptowano: 25 października 2021

Accepted: 25 October 2021

\section{Sugerowana cytacja / Suggested citation:}

Rudewicz, J. (2021). Przeobrażenia przestrzenno-funkcjonalne terenów poportowych w Szczecinie w świetle klasycznych modeli miasto-port. Prace Komisji Geografii Przemysłu Polskiego Towarzystwa Geograficznego, 35(4), 109-127. doi: https://doi.org/10.24917/20801653.354.7

\section{WSTĘP}

Miasto portowe egzemplifikuje współzależność środowiska przyrodniczego i człowieka tworząc charakterystyczne środowisko geograficzne. Związek miast i portów jest zjawiskiem obecnym w całej historii cywilizacji, której przejawem jest zorganizowane życie miejskie. Od starożytnych kultur Morza Śródziemnego, Oceanu Indyjskiego, Chin, po dzień dzisiejszy. Miasto i port poprzez uwarunkowania ekonomiczne, przestrzenne i historyczne wytworzyły formy zagospodarowania charakteryzujące się specyficznym krajobrazem i funkcjami. Miasto portowe według Flisa to „miasto, którego główną funkcją miastotwórczą jest przeładunek towarów oraz transfer pasażerów z drogi lądowej na drogę wodną i odwrotnie. Charakter portowy posiadają m.in. Aleksandria, Rotterdam, Hamburg, Gdańsk i Szczecin" (Flis, 1985: 209). W artykule w sposób przeglądowy i retrospekcyjny ukazano relacje i zmiany przestrzenno-funkcjonalne miast portowych odnosząc się do prób ich modelowego uchwycenia obecnych w literaturze. Według prof. Runge w przeobrażeniach miast i regionów biorą udział trzy struktury: struktura funkcjonalna, struktura przestrzenna oraz struktura demograficzno-społeczna. Struktura funkcjonalna wskazuje na dominujące działalności gospodarcze, zwłaszcza w układzie: sektor egzo/endogeniczny. Sektor egzogeniczny koncentruje działalności gospodarcze, które determinują rolę miasta w szerszej skali przestrzennej, a zarazem decydują o zakresie udziału w rynku pracy. Struktura przestrzenna odzwierciedla zróżnicowanie morfogenezy i morfologii form użytkowania w obrębie jednostki terytorialnej. Jest efektem lokalizacji, zmian oraz nakładania się na siebie różnego typu działalności człowieka (więcej: Runge, 2018). Relacje przestrzenne - pojęcie stosowane w artykule - według definicji obejmują właściwości zjawisk występujących w przestrzeni geograficznej: stopień rozproszenia lub skupienia na danym obszarze (gęstość), odległość między różnymi obiektami, sąsiedztwo obiektów względem siebie oraz powiązania między obiektami (Żyszkowska, Spallek, Borowicz, 2012: 120).

Na kanwie odniesień do modeli teoretycznych, w artykule dokonano retrospekcji wzajemnych relacji przestrzennych terenów portowych i miejskich w Szczecinie oraz naszkicowano obecny i planowany rozwój terenów poportowych w obrębie wyspy Łasztownia. Na tym tle pojawia się pytanie, czy port w obecnych realiach ekonomicznych i społecznych stanowi nadal istotny czynnik miastotwórczy? Port oraz związane z nim zaplecze przemysłowe i handlowe poprzez lata rozwoju ekonomicznego, demograficznego i przestrzennego danego miasta, zmiany w technice przeładunku, rozwoju zaplecza, skomunikowania i skali obiektu sprawiają, że zmieniają się relacje przestrzenne pomiędzy portem a miastem. Dlatego rodzi się w tym miejscu kolejne pytanie, czy obecne tereny portowe tworzą z miastem całość, czy też osobną strukturę? Obok przeglądu i porównań Szczecina z modelami teoretycznymi (ze względu na czas powstania 
nazwanych w artykule klasycznymi) celem artykułu jest próba wskazania uwarunkowań kształtujących obecne miejsce portów w strukturze przestrzenno-funkcjonalnej miast. Znaczna część portów posiada obszary będące terenami zdegradowanymi, ale o dużym potencjale do wykorzystania i nadającymi się do rewitalizacji. Mogą one powrócić do miast, często „głodnych” przestrzeni zmieniając swoją funkcję i intensyfikując odbiór portowego charakteru miasta wśród mieszkańców i turystów. Cele artykułu i odpowiedzi na pytania starano się osiągnąć poprzez: przegląd literatury, retrospekcję i obserwację, studium przypadku oraz analizę porównawczą.

\section{PodBUDOWA TEORETYCZNA, MODELE PRZESTRZENNO-FUNKCJONALNE MIAST PORTOWYCH}

Obok definicji miasta portowego podanej przez Flisa istnieje wiele innych w krajowych i zagranicznych aktach prawnych (więcej: Gostomski, Nowosielski, 2021). Brocard (1994), uważa miasto portowe za miasto, w którym prowadzi się działalność portową i morską. Miasto takie jest również uważane za węzeł komunikacyjny między sieciami komunikacyjnymi lądowymi i morskimi, pełniącymi rolę pomocniczą i mający silny wpływ na przestrzenną organizację regionu stanowiącego jego zaplecze. W definicjach zestawia się ze sobą dwie role miasta portowego, funkcję przeładunkową i funkcje bramowe (za Ducruet, 2011) oraz podkreśla jego złożoność jako organizmu gospodarczego i posiadanie związków z gospodarką morską (Palmowski, Pacuk, Michalski, 2001). Miasto portowe można uznać za „system” (Forno, 1985). Jest to miasto, w którym działalność portowa i morska mają duży wpływ na lokalną gospodarkę, tak że miasto zależy od istnienia portu. Taką koncepcję często można znaleźć w dziełach historyków świata kolonialnego (Borruey, 1992; Borruey, Fabre, 1992). Uważali oni, że miasta portowe mają odrębną specyfikę, wystarczającą, by utworzyć osobną kategorię miejską, domyślnie twierdząc, że każde miasto portowe jest budowane przez istnienie identycznych mechanizmów. Definicje nie oddają całego spektrum złożoności form koegzystencji miasta i portu. Dlatego kwestie definicji powiązano z typologiami miast portowych, podkreślających różnorodność istniejących konfiguracji przestrzennych i ekonomicznych takich miast. Vigarié (1979) wyróżnił trzy możliwe konfiguracje:

- Aglomeracja o wyraźnych funkcjach portowych, nawet jeśli odsetek miejsc pracy w porcie nie stanowi większości zatrudnienia w miastach, np. Hawr;

- Aglomeracja z mniej wyraźną funkcją portową. Lądowa tkanka przemysłowa w niewielkim stopniu powiązania jest z żeglugą, np.: Rouen, Manchester, Szczecin;

- Aglomeracja z mniej wyraźnymi funkcjami portowymi - duże i silne ekonomiczne miasta i stolice nadmorskie: Nowy Jork, Londyn, Hamburg, Kopenhaga.

Kolejna typologia O'Connora (1989) wynika z badań australijskich miast portowych. Zbudowana jest na proporcji usług i uprzemysłowienia typowych dla portu a poziomem metropolitalności - istnienia w mieście usług wyższego rzędu. Autor ten wyróżnił:

- Port city (miasto-port) - dominuje w nim funkcja tranzytowa, polegająca głównie na obsłudze i fizycznych przepływach towarów i osób;

- Przemysłowe miasto nadmorskie charakteryzuje się rozbudowanym przemysłem i szerszym zakresem usług wyższego rzędu, w tym finansowych i pośrednictwa w handlu; 
- Miasto międzynarodowe - globalne lub znaczące miasto morskie, często największe miasto $\mathrm{w}$ kraju, decyzyjnie wpływające na wieloletnią politykę rozwoju szlaków morskich, pośredniczące w międzynarodowym rynku finansowym.

Z kolei Seassaro (1992) porównuje proporcje funkcji zarządczych z funkcjami wykonawczymi (przeładunkowymi) - wykonywaniem zadań w portach, co prowadzi do sformułowania czterech głównych typów, mniej lub bardziej wyspecjalizowanych miast $\mathrm{w}$ tranzycie portowym:

- Międzynarodowa metropolia - pełni funkcje wykonawcze i zarządzania, jest połączeniem wiązki wielu sieci transportowych i miejscem wydajnej bazy gospodarczej;

- Miasto portowe niższego rzędu - pełni zwykle funkcje wykonawcze, posiada mniej połączeń sieciowych, jego baza ekonomiczna jest mniej produktywna;

- Upadłe lub tradycyjne miasto portowe - pełni tylko funkcje przeładunkowe;

- Monofunkcyjne miasto portowe - ograniczone do wąskiego, wyspecjalizowanego zakresu funkcji wykonawczych i zarządczych.

Typologia Marcadona (1997) opiera się na kryterium wielkości i złożoności organizacyjnej portów i ich relacjami z miastem - autor ten wyróżnił:

- Port metropolitalny - posiadający warunki dla kompleksowego zakresu działalności portowej, usługowej oraz przemysłowej;

- Port średniej wielkości, który oferuje mniejszy zakres zaawansowanych operacji portowych, może mieć ograniczony dostęp do akwenów, często ma charakter będącego w przeszłości znaczącego miasta w morskiej wymianie handlowej;

- Port drugorzędny - charakteryzujący się przewagą funkcji odbioru (grupowanie, dzielenie ładunków, skład) oraz względnym brakiem obszaru miejskiego o zróżnicowanych funkcjach.

Typologie powyższe wskazują, że istnieje rozróżnienie pomiędzy miastami portowymi posiadającymi funkcje administracyjne i decyzyjne oraz tymi, które posiadają jedynie funkcje wykonawcze. Pierwsze łączą wszystkie funkcje (baza produkcyjna i handlowa, rozbudowany sektor usług), a drugie ograniczają się do obsługi przeładunków. W pierwszych funkcje portowe wygenerowały bezpośrednie lub pośrednie efekty miastotwórcze (np. rozwój usług, powstanie dzielnic mieszkalnych, indukowanej działalności gospodarczej), niektóre mogły oderwać się od związków z działalnością portową. Badacz problematyki miejsko-portowej, Ducruet sformułował inną typologię (Ducruet, 2005) (rycina 1). Zaobserwował istnienie dynamicznych przejść między wielkością i znaczeniem miasta a wielkością ruchu portowego. Na osi poziomej macierzy typologicznej oznaczono kryterium ruchu portowego w trzech stopniach natężenia: niskim, średnim i wysokim, na osi pionowej wielkość miasta. Kombinacje wielkości miasta i portu ilustrują znaczenie zmiennych, ekonomicznych i przestrzennych dla tych dwóch bytów, co stanowi nawiązanie do wymienionych wyżej typologii. Macierz ukazuje synkretyzm miasta i portu oraz możliwe ścieżki ewolucji tych dwóch „bytów”. Możliwe trajektorie czasoprzestrzenne ich rozwoju, od wioski nadmorskiej do globalnej metropolii portowej skupiającej na swym obszarze pełen katalog funkcji miejskich i portowych.

Przechodząc od typologii do opisu modeli relacji przestrzennych miasto-port, te bliższe współczesności są bardziej statyczne i skupiają się na różnych skalach przestrzennych, od miasta po region portowo-przemysłowy. Ich cechą są częstsze opisy i analizy zależności ekonomicznych, technicznych i logistycznych. Spotykane są 
Rycina 1. Macierz relacji między portem a miastem

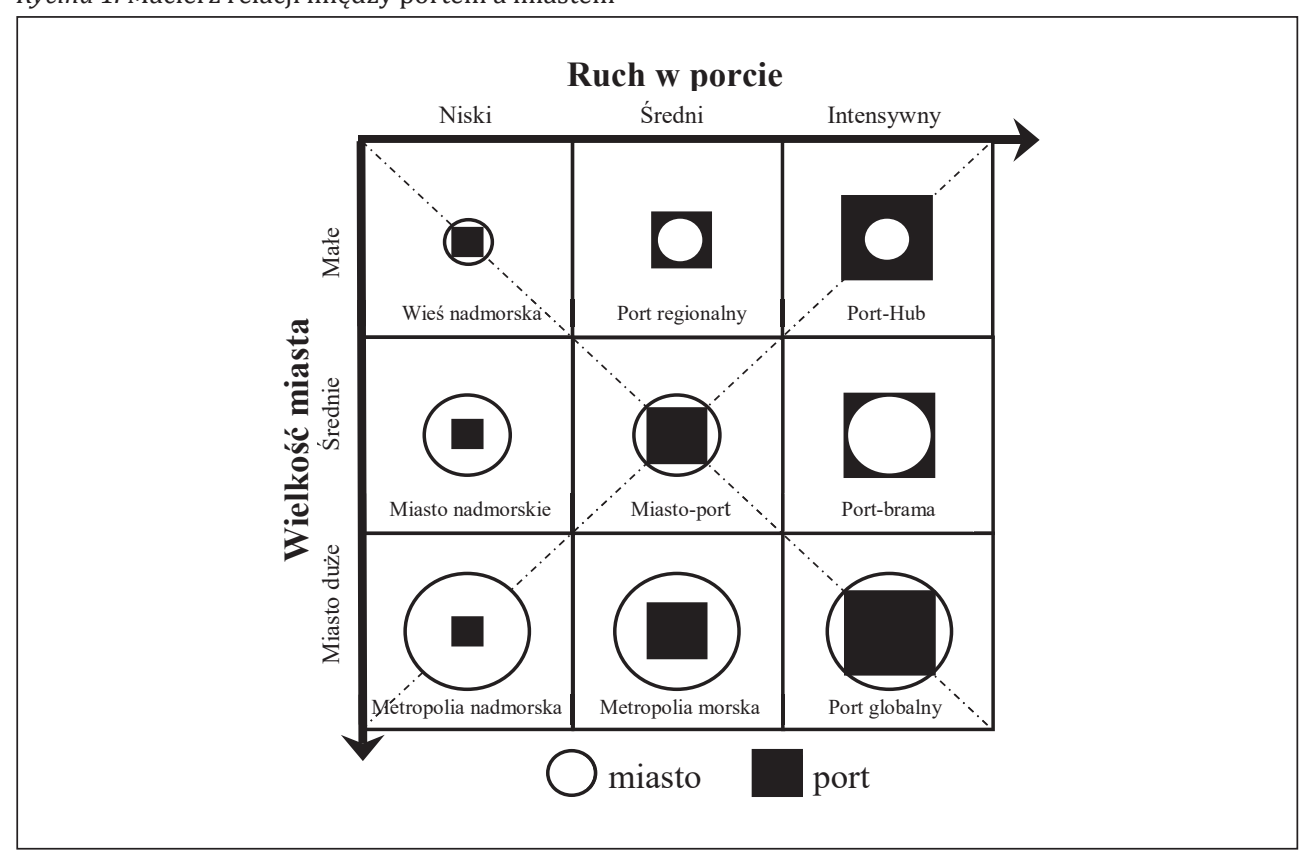

Źródło: Ducruet (2005)

również modele przestrzenne w sekwencji czasu, ewolucyjne, ukazujące w sposób dynamiczny wspomniane relacje między komponentami systemu miasto-port.

Były prezydent Szczecina, urbanista prof. Zaremba - analizując rozwój miast portowych na przestrzeni stu lat (1862-1962) uważa, że w mieście portowym współistnieją cztery silne organizmy: port, miasto, przemysł i węzeł komunikacyjny. Konkurencja między tymi „organizmami”, brak koordynacji doprowadza często do konfliktów i złych decyzji lokalizacyjnych. Powoduje np. zjawisko deglomeracji przemysłu portowego. Zaremba analizował ewolucję portowo-miejskich układów przestrzennych na świecie, wyróżnił w jej przebiegu trzy fazy koegzystencji (relacji) miasta i portu. Okres pierwszy - powolnego rozwoju miasta i portu w oparciu o proste niezmechanizowane środki techniczne dostosowane do żaglowców o małym tonażu. W okresie tym zauważa się równowagę w rozwoju portu i miasta, który mieści się w „skali człowieka”, nie przytłacza go swoim ogromem. Okres drugi - nagłego rozwoju techniki i żeglugi, w którym postęp techniczny był tak szybki, że problemy ściśle techniczne zdominowały problematykę życia miejskiego. W okresie tym brakuje równowagi pomiędzy rozwojem portu i miasta, przeważają wyraźnie antagonizmy rozwojowe. Miasto portowe rozwija się dynamicznie i żywiołowo, ale nie zawsze zyskują na tym jego mieszkańcy. Ich potrzeby bytowe, kulturalne i estetyczne nie są w pełni zaspokajane. Port rozsadza i rozpycha miasto, a komunikacja kolejowa nie obsługuje należycie miasta. Okres trzeci - urbanistycznego planowania, gdzie powoli toruje sobie drogę przeświadczenie o konieczności kompleksowego rozwiązywania problemów miasta, portu i przemysłu. W analizowanej koncepcji miasto portowe składa się z dwóch podstawowych elementów. Portu, będącego miejscem przeładunku i macierzystą bazą taboru morskiego i miasta, stanowiącego bazę usługową dla pracy portu oraz miejsce produkcji powiązanej 
z gospodarką morską. Zaremba sugeruje w trzeciej fazie konieczność interwencji planistycznej i zwiększenie sprawczej roli osób decydujących o rozwoju miasta i portu (Zaremba, 1962: 53). Należy zwrócić uwagę, że autor wyżej wymienionej koncepcji działał aktywnie jako urbanista w okresie powojennym oraz w okresie gospodarki centralnie sterowanej.

Miasto portowe w szerszym kontekście sytuacyjnym zaprezentowano w modelu Vigarié. Autor traktuje port jako kontinuum, a nie odrębną dychotomiczną jednostkę. Port jest w centrum systemu, po jego obu stronach znajduje się lądowe zaplecze oraz obszary zamorskie (foreland). Port jest obszarem skupiającym wiązki szlaków transportowych pomiędzy wymiarem lądowym i oceanicznym (terenami zamorskimi), ale także ogniwem pośredniczącym w organizacji produkcji przemysłowej i transportu. Dynamika przepływów w tych elementach - morskim, lądowym i wewnątrz portu ma znaczenie dla rozwoju portu i pośrednio miasta portowego. Zmiana technologiczna i logistyczna, zastosowanie kontenerów - międzynarodowego standardu załadunku towarów, zmieniło rozmiar całego systemu logistycznego. Korzyści wynikające z zastosowania kontenerów doprowadziły do opracowania specjalistycznej infrastruktury portowej. Przyjęcie zestandaryzowanego „formatu” doprowadziło do koncentracji portów i wzrostu wielkości ładunków (Vigarié, 1979). Trasy morskie zostały również przeprojektowane poprzez wprowadzenie linii „Round-the-World” oraz stworzenie pośrednich centrów przeładunkowych, które umożliwiają dalszą racjonalizację i koncentrację przepływów. Tworzenie dedykowanych terminali obsługiwanych przez tych samych operatorów w skali globalnej sprawiło, że transport morski stał się współzależną siecią (Notteboom, 1997). Koncentracji przepływów morskich towarzyszy polaryzacja i koncentracja ruchu na lądzie. Sieć szlaków transportowych, centrów przeładunkowych, magazynów lub składów w głębi lądu jest rozmieszczona symetrycznie w stosunku do sieci portów.

Modelem zbudowanym w mniejszej skali urbanistycznej jest „anyport model” Birda. Model powstał w wyniku analizy brytyjskich badaczy portów morskich. W modelu anyport (rycina 3) rozwój przestrzenny portów składa się z chronologicznych faz. Każda faza ma swój unikalny fizyczny układ obiektów i funkcji portowych ze względu na zmiany technologiczne w transporcie żeglugowym i przeładunkach, np. z ładunków masowych na ładunki kontenerowe. Są to baseny, nabrzeża, pirsy, tereny składowe, infrastruktura transportu lądowego. Postęp w handlu morskim wyznacza tempo rozwoju portów. Trendy w rozwoju portów, wykazane w modelu Birda, pokazują, że specjalizacja działalności portowej wyparła obszar portu z centrum miasta i skierowała infrastrukturę portową w dół rzeki. Port „poszukuje” głębszych akwenów w miarę powiększania się i zanurzenia jednostek pływających i konieczności podniesienia zdolności przeładunkowych infrastruktury portowej. W pierwszej fazie miasto i port stanowią zwartą całość, w kolejnych fazach dochodzi do ekspansji portu i specjalizacji przestrzeni w samym porcie. Ostatnia faza to powstanie regionu portowego (Bird, 1963: 132-133).

W prostszej wizualnie formie wzajemne relacje przestrzeni miasta i portu zaprezentowali Norcliffe, Basset, Hoare. Model analizuje relacje miasta i portu w czterech fazach. W pierwszej $\mathrm{t} 1$ (rycina 4), miasto i port stanowią symbiotyczną całość. W miarę postępu technologicznego, rozwoju gospodarczego, efektami skali oraz przeobrażeń utożsamianych zdaniem autorów z postmodernizmem miasto i port „oddalają się”. Zmniejsza się powierzchnia, długość tzw. brown waterfronts - obszarów nawodnych zajętych przez port i powiązany z nim przemysł (t2). W trzeciej fazie „wysysania” (t3) 
Rycina 2. Model zaplecze-port morski-morze

Przestrzeń morska i zamorska (foreland) Przestrzenie na lądzie (hinterland)

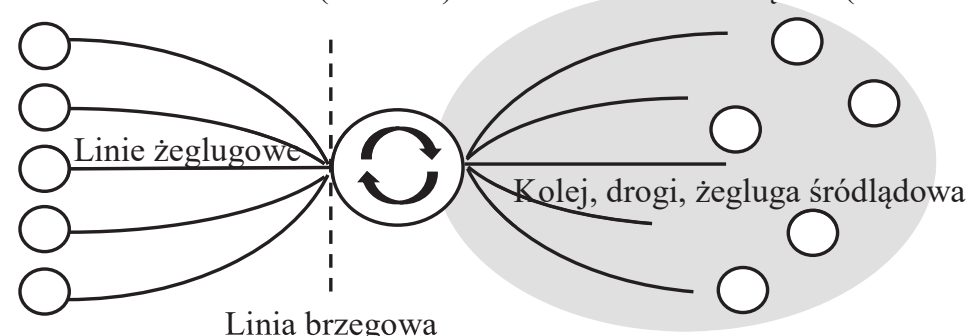

Powiązane porty $\quad$ Destynacje lądowe

Źródło: Vigarié (1979): The hinterland-seaport-foreland or port triptych model

Rycina 3. Anyport model. Ewolucja połączeń między miastami nadmorskimi a portami

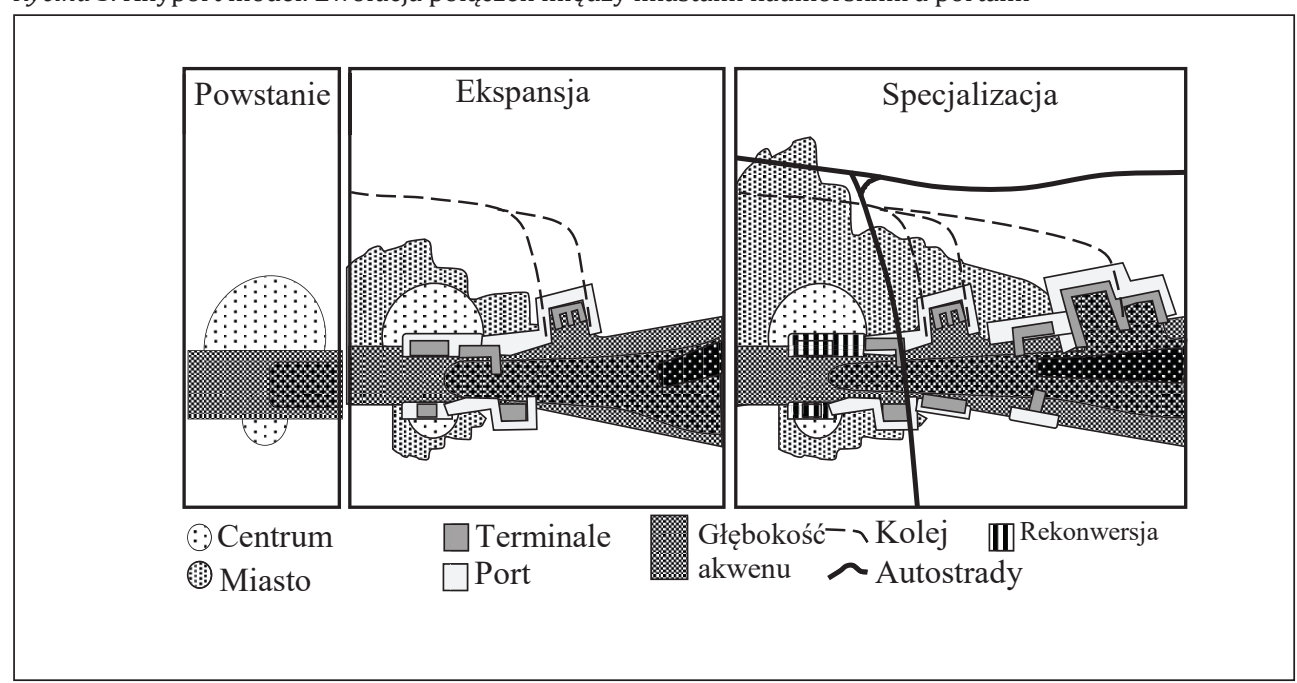

Źródło: Bird (1963)

miasto rywalizuje o tereny inwestycyjne z portem o atrakcyjne tereny nawodne. W wielu miastach wycofanie działalności portowej z centralnego obszaru miasta odbyło się w latach 70. i 80. XX wieku. Uwolniły się wówczas tereny wcześniej wykorzystywane do działalności przemysłowej związanej z portem (przykład Toronto). Dostrzeżono, że opuszczone nabrzeża stwarzają wiele nowych możliwości obejmujących budownictwo mieszkaniowe, hotele, atrakcyjne dziedzictwo poprzemysłowe, tereny dla sportu i rekreacji, turystyki i lokalnego handlu - atrakcyjne „waterfronty” . W innym przypadku (t4), gdy tereny o cechach miejskich wkraczają na tereny portowe, dochodzi do powstania konfliktu pomiędzy funkcjami miejskimi i portowymi. Może do tego dojść w sytuacji większej ekspansji przestrzennej miasta.

W pewien sposób podobny do modelu przedstawionego wyżej relacje przestrzenne miasta i portu wyraża model Hoyle'a (1998). Autor tego modelu zastosował podejście ewolucyjne wiążąc etapy rozwoju gospodarczego i technologicznego świata 
Rycina 4. Model przejścia miasto-port

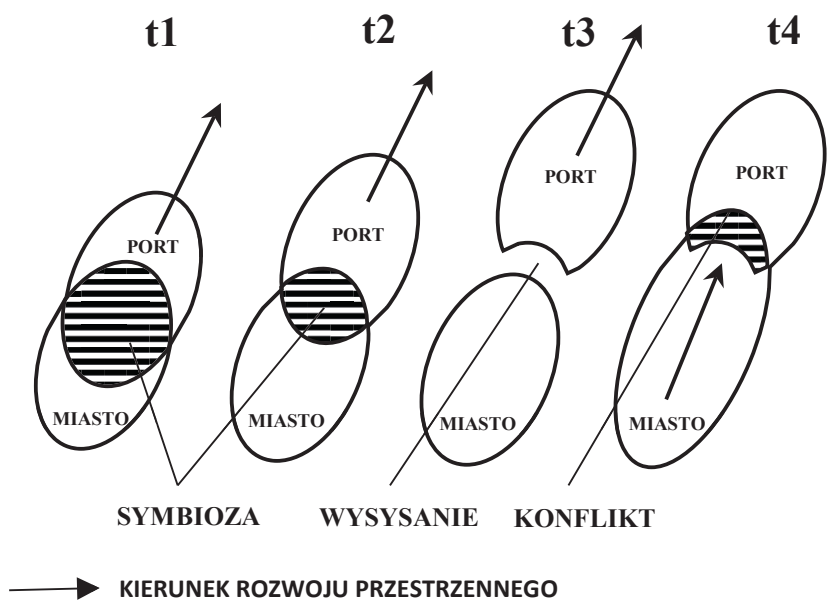

Źródło: Norcliffe, Basset, Hoare (1996)

z rozwojem relacji miasto-port (rycina 5). Wywód Hoyle'a oparty o badania portów hiszpańskich, portugalskich oraz afrykańskich generuje pytanie „cityport or port city?” Idea portu miejskiego wywodzi się z bliskiego związku między portem a miastem, jest on jego główną częścią składową. Związek ten może być zakorzeniony w historii rozwoju miasta, powiązany z morską, wielowiekową działalnością handlową. Port i miasto mogą istnieć obok siebie w stanie współzależności lub bez wzajemnych powiązań. Hoyle zwraca również wyraźnie uwagę na czynniki lokalizacyjne portów, uzupełniane przez szczegółowe warunki związane z miejscem. Zarówno po stronie lądu jak i wody, które przez swój determinizm przestrzenny mogą wpływać na relacje miasta i portu. Mogą wpływać na długoterminowy rozwój portu, gdzie decyzje dotyczące rozbudowy portu często wpływały na wzorzec rozwoju miasta. Warto mieć na uwadze, że lokalizacja portu wynika często z przyczyn leżących wewnątrz lądu, np. silny ekonomicznie region wpływał na warunki ich rozwoju. W modelu Hoyle’a wyróżnił siedem stadiów rozwojowych miast portowych. Od czasów starożytnych do dziewiętnastego wieku współistnienie portu i miasta w jednym pierwotnym miejscu wiąże się z maksymalną współzależnością funkcjonalną. Nabrzeża często przejmowały rolę punktu centralnego całej osady, czego przykładem jest XV-wieczna Genua. Rewolucja przemysłowa, kolej i statki parowe oraz rozwój przemysłu, wzmacniany przez potrzeby transportowe wynikające z zamorskiej ekspansji kolonialnej Europy, sprawił, że rozwój portów przyspieszył, stały się one bardziej wyspecjalizowane. Współczesne przemysłowe miasto portowe wyróżnia separacja między obszarem miejskim a portem. Szczególnie gdy port powiązany jest z przemysłem rafineryjnym, zbiornikami, składami materiałów masowych, terminalami kontenerowymi. Separacja współczesna wynika również ze zmian historycznych, które zlikwidowały dawne podziały społeczne, dając robotnikom większe prawa i lepsze warunki życia w miejskich obszarach rezydencjalnych. 
Rycina 5. Etapy ewolucji relacji port-miasto wg Hoyle'a

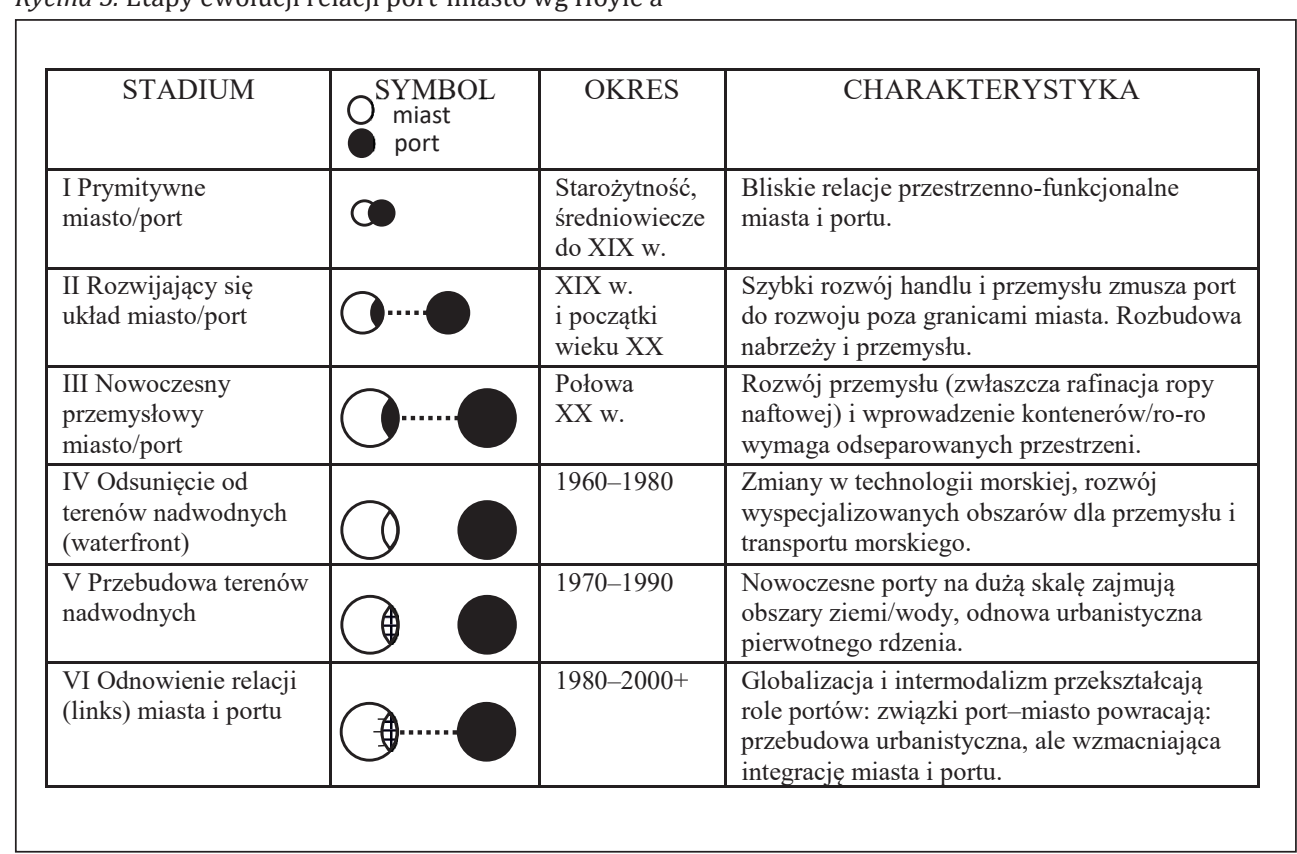

Źródło: Hoyle (1998)

\section{STREFA INTERFEJSU - STYKU MIASTA I PORTU}

Syntetyczny model Hayutha zawiera informacje wprost prowadzące do wyjaśnienia powstania strefy interface - przejścia, styku miasta i portu. Zwaną też strefą schyłku i rozkładu „decline and decay”, obszaru problemowego. Schemat ten reprezentuje podejście systemowe, najbardziej holistyczne ze wszystkich prac poglądowych zaprezentowanych w tekście - rycina 6 . Podobnie jak w innych modelach, zestawione są ze sobą miasto i port. Trendem, który ma najsilniejszy wpływ na modyfikacje we wzajemnie oddziałujących ze sobą podsystemach (przestrzennym, ekonomicznym i ekosystemie), są zmiany technologiczne i logistyczne. Zmiany, których konsekwencją jest powiększenie się tonażu statków oraz zmiany w sposobie przechowywania ładunków i ich transporcie (Hayuth, 1982). Współczesne największe kontenerowce z serii Triple-E, (Economy of scale, Energy-Efficient) kursujące między Azją a Europą mają długość ponad $400 \mathrm{~m}$ i ładowność blisko 20000 TEU oraz zanurzenie robocze $16 \mathrm{~m}$.

Obsłudze drobnicowej towarzyszą masowce i statki specjalistyczne w tym gazowce i chemikaliowce oraz jednostki pływające do obsługi działalności offshore - wydobycia ropy naftowej, budowy platform wiertniczych, morskich siłowni wiatrowych, jednostki ro-ro oraz turystyczne cruisery. Działalności portowej towarzyszy przemysł przetwórczy, elektromaszynowy, petrochemiczny. Porty to również infrastruktura transportowa, oczyszczalnie wód zęzowych, instalacje bezpieczeństwa, baza paliwowa, składy i magazyny. Czynnikiem kształtującym strefę interface, pojawiającym się od strony miast, jest rosnąca zmiana postaw społecznych w stosunku do terenów nawodnych. 
Rycina 6. Trendy w rozwoju miasta i portu

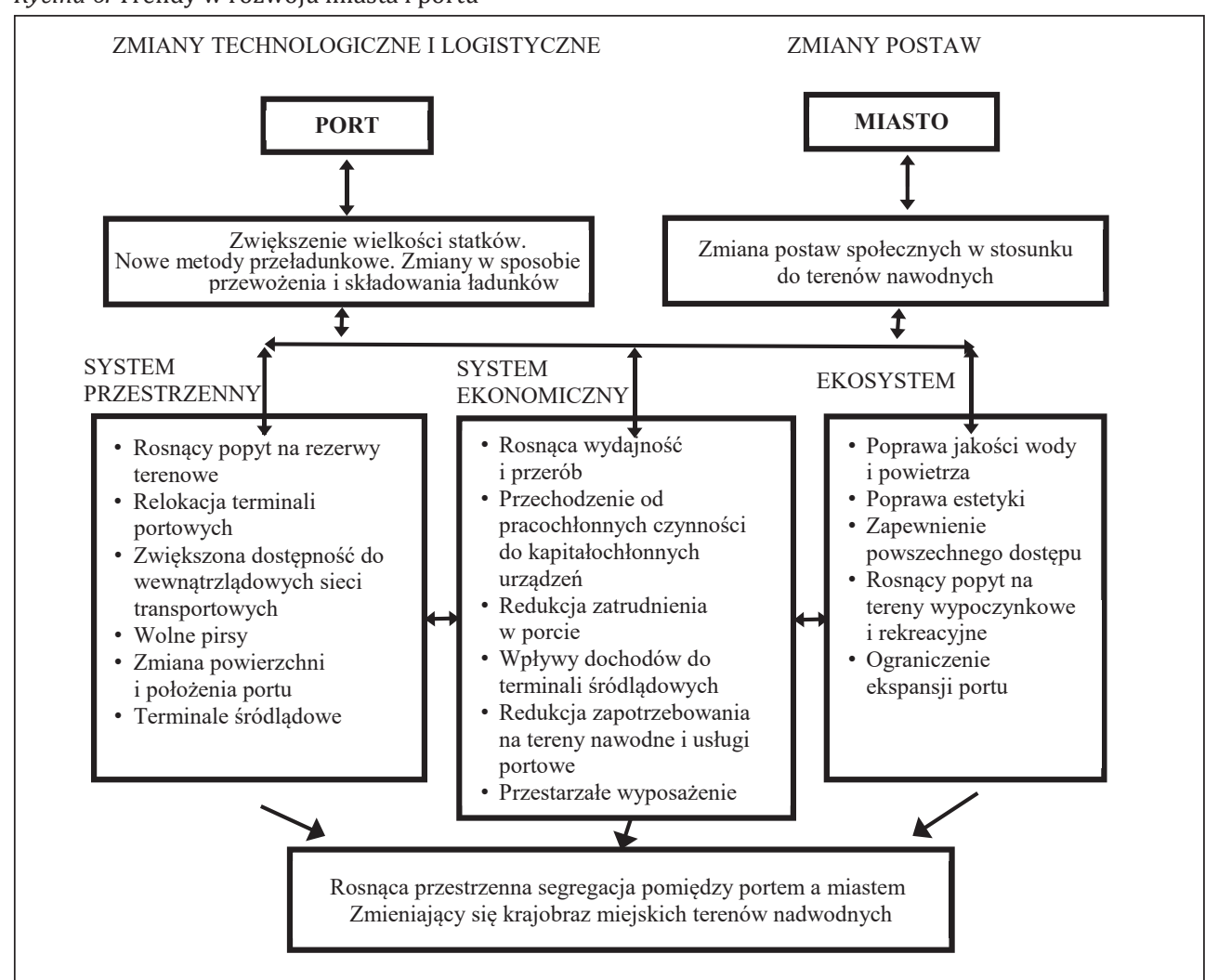

Źródło: opracowanie własne na podstawie Hayuth (1982)

Miasta dzięki zagospodarowaniu terenów nadwodnych mogą kreować swój wizerunek morskości tworząc na tym obszarze atrakcyjne przestrzenie (Cowan, Bunce, 2006).

Należy zauważyć, że lepsza jakość wód portowych wpływa na powrót zainteresowania basenami portowymi. Efektem oddziaływania trendów we wzajemnie powiązanych podsystemach: przestrzennym, ekonomicznym i ekosystemie jest rosnąca przestrzenna segregacja pomiędzy portem a miastem. Opisane na schemacie (rycina 6) skutki oddziaływania trendów będą wzmacniane w przyszłości poprzez większą automatyzację procesów portowych i masę ładunków. W przyszłości dekarbonizacja gospodarki może zmniejszyć wolumen transportu towarów masowych np. węgla i materiałów ropopochodnych, jednocześnie zwiększając presję na niskoemisyjność procesów portowych i obsługę nowych intermodalnych sposobów transportu z i w głąb lądu. Uzupełnieniem powyższego modelu relacji miasta i portu jest teoretyczne ujęcie dynamiki wpływu wiodących trendów na rozwój miasta i portu oraz ich konsekwencje przestrzenne dokonane przez Hoyle'a (rycina 7). Kluczowym obszarem w przestrzennych relacjach miasta i portu jest strefa kontaktu tych przestrzeni - wspomniana strefa interface. Uwidacznia się ona w ostatnich dwóch etapach ewolucji układu miasto-port.

Dochodzi w niej do relokacji i rekonwersji aktywności gospodarczej i zmiany wielu funkcji. Wpływ zmian w technologii transportu morskiego, zmian legislacyjnych (np. dotyczących bezpieczeństwa, ochrony środowiska), zmiany strukturalne w przemyśle 
Rycina 7. Dynamika rozwoju strefy przejścia miasta i portu

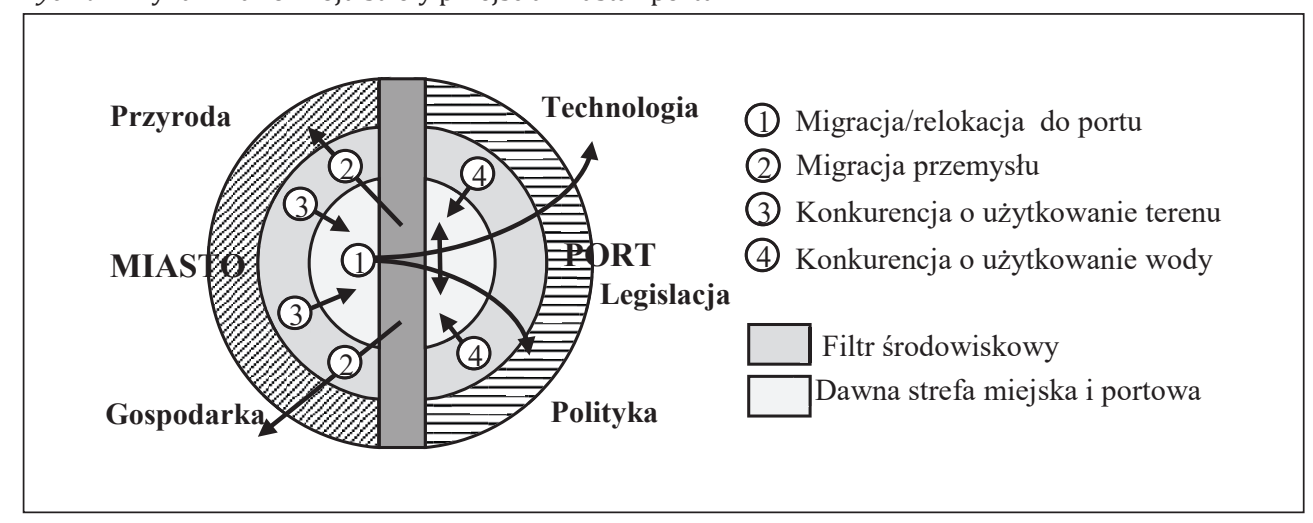

Źródło: Hoyle (1988)

towarzyszącemu działalności portowej sprawia, że w funkcji czasu funkcje portowe i przemysłowe były i są relokowane dalej poza obszar miasta lub w głąb terenów portowych i węzłów transportowych.

Relokacja (1) dotyczy uciążliwych i niebezpiecznych czynności portowych. Uwarunkowania środowiskowe i ekonomiczne: uciążliwość emisji, terenochłonność, energochłonność, wodochłonność, bezpieczeństwo (przykład wybuchu saletry w porcie Bejrucie) renta gruntowa itd. wpływają na sens prowadzenia tam działalności gospodarczej, w efekcie przenosi się ona na odległe tereny portowe. Z kolei przemysł, który może uniezależnić się od lokacji portowej, przenosi się dalej na inne tereny miejskie i podmiejskie lub do stref przemysłowych (2). Powstaje w ten sposób obszar atrakcyjny zarówno z punktu widzenia niektórych podmiotów gospodarczych (3), jak i budownictwa mieszkaniowego (np. lofty) - pojawiają się tam usługi restauracyjne, kompleksy handlowe. Miejsce to jest atrakcyjne także z punktu widzenia usług morskich i aktywności nadwodnych (4) (mariny, rekreacja, obiekty wodne, żegluga indywidualna). Brak pewnej synchronizacji w czasie tych procesów, inercja po stronie aktywności miejskiej - inwestycyjnej, może powodować degradację tych terenów pod względem krajobrazowym, oraz opóźnienie zagospodarowania pod nowe funkcje.

\section{SZCZECIN - MIASTO I PORT, REWITALIZACJA, ANALOGIE DO MODELI RELACJI MIASTA I PORTU}

Retrospekcja relacji przestrzennych miasta i portu w przypadku Szczecina w koresponduje z założeniami zaprezentowanych wyżej modeli. Początkowo miasto Szczecin i port stanowiły jedną całość. Znaleziska archeologiczne słowiańskich łodzi z IX wieku oraz badania zabudowy świadczą, że port i miasto Szczecin mają wspólną genezę. We wczesnym średniowieczu port zlokalizowany był na lewym brzegu Odry Zachodniej u podnóża grodu ówczesnych książąt pomorskich z dynastii Gryfitów. Później na obszarze pomiędzy Odrą Wschodnią Regalicą a Odrą Zachodnią tzw. Międzyodrzu. Rozwijając się w tę stronę port miał więcej bezpiecznych i otwartych terenów. Port ulokowany był w stosunkowo płytkich wodach - około 1,5 metra w odległości około 40 km w linii prostej od otwartych wód morskich Bałtyku. Głębokość ta była wystarczająca dla łodzi o wyporności do 5 ton, był to port śródlądowy - rzeczny i częściowo 
Rycina 8. Schemat rozwoju portu w Szczecinie na podstawie modelu Hoyle’a (rycina 5)

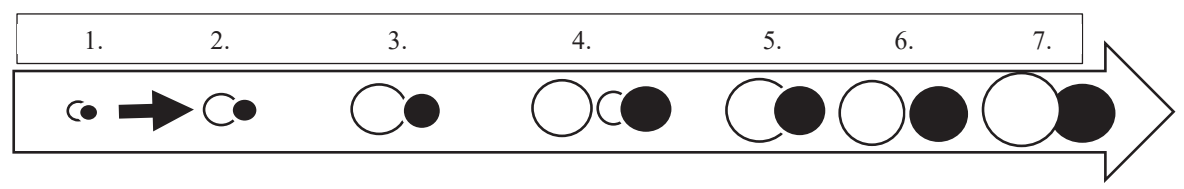

Port symbolizuje czarne koło, miasto koło białe.

Źródło: opracowanie własne

morski. W XIII wieku port rozwijał się na wyspie Łasztownia, bliżej głównego nurtu rzeki, poniżej murów miasta. Od południa ograniczony został przez Most Długi, a od północy przez Most Kłodny. Lokalizacja portu między dwoma mostami uregulowana została prawnie i utrzymana do połowy wieku XVIII. Na zewnątrz portu funkcjonowały mniejsze przystanie, służyły one miejscowej ludności trudniącej się rybołówstwem (więcej: Kotla, 2007; Zarząd Morskich Portów..., 2021). Szczegółowe opisy historyczne dotyczące portu i miasta wyczerpałyby ramy artykułu i zmieniły jego cele, dlatego dokonano porównania rozwoju układu miasto Szczecin-port z modelem ewolucji miasta i portu Hoyle'a (rycina 5) skupiając się na przełomowych momentach rozwoju tych dwóch układów przestrzennych. Na schemacie miasto oznaczone jasnym okręgiem, port - ciemnym. Nachodzenie na siebie okręgów symbolizuje symbiozę obu obszarów, wielkości - proporcje powierzchni portu i miasta (rycina 8).

Kluczowe momenty w ewolucji układu przestrzennego miasta i portu w Szczecinie:

1. Bogate słowiańskie grodzisko portowe z X wieku. 1243 rok - nadanie praw miejskich. W 1278 roku miasto zostało członkiem Hanzy. W roku 1283 wzmiankowano o budowie Mostu Długiego na Odrze (Hansabruecke).

2. Po 1648 roku, w wyniku pokoju westfalskiego, Szczecin należał do Królestwa Szwecji. Obowiązywały wtedy wysokie cła uniemożliwiające rozwój handlu, a tym samym portu.

3. W latach 1662-1668 wybudowano kanał łączący Odrę ze Sprewą, dzięki czemu Szczecin uzyskał bezpośrednie połączenie wodne z Berlinem. Po 1679 roku obniżono cła dla szczecińskich kupców i zniesiono opłaty celne na wyroby szczecińskich manufaktur, co rozwinęło handel morski i lądowy. Do drugiej połowy XIX wieku rozwój portu ograniczał się do brzegów Odry między Mostem Długim i Kłodnym.

4. Szczecin w latach 70. XIX wieku przestał pełnić rolę obronną i warowną, którą rozwijano od 1630 roku. Zdecydowano o likwidacji twierdzy Stettin. Fortyfikacje izolowały miasto od otaczających je miejscowości, np. osobnego miasta Grabowo (niem. Grambow), obecnie integralnej części miasta, które dynamicznie się rozwijały w oparciu o funkcje portowe i przemysłowe. W 1877 roku został wybudowany na Kępie Parnickiej dworzec kolejowy i linia kolejowa łącząca port z drogą kolejową prowadzącą do Kostrzyna, a w kolejnym roku doprowadzono kolej do nowych nabrzeży przy Duńczycy (kanał). Dworzec ten zlikwidowano w 1896 roku pozostawiając nowoczesny układ kolejowy obsługujący port, połączenia z Berlinem i Wrocławiem. Wzrost ilości przeładunków wymusił rozbudowę terenów portowych. Początkowo nowe nabrzeża sytuowano wzdłuż brzegów Parnicy i Duńczycy. Na przełomie XIX i XX wieku, gdy te już nie wystarczały, nabrzeża zaczęły powstawać 
wzdłuż zachodniego brzegu Odry, a na Łasztowni (rycina 9) wybudowano dwa baseny portowe (Basen Wschodni i Zachodni) wraz z urządzeniami przeładunkowymi i zapleczem magazynowym. Powstał także Basen Górniczy (przeładunki masowe). Znaczna rozbudowa portu w tym czasie wynikała głównie z polityki rządu pruskiego, który dostrzegł w Szczecinie port zdolny oprzeć się blokadzie alianckiej na wypadek wojny. W okresie I wojny światowej Szczecin był największym portem niemieckim. W dwudziestoleciu międzywojennym rozwój portu zatrzymał się, by bliżej II wojny nabrać znaczenia militarnego. Znane są plany daleko idącej rozbudowy portu stworzone przez nazistów. Miasto i port nadal łączyła rozległa strefa handlu, spichlerzy i magazynów - Bollwerk.

5. Bombardowania i dywersja w końcowej fazie II wojny światowej unieruchomiły port, jego dewastacji dokonały też wojska radzieckie. Inwentaryzacja powojenna wykazała w porcie 80\% zniszczeń. Zniszczone były urządzenia (np. wszystkie 152 dźwigi), akweny były zatarasowane wrakami. Całkowite zniszczenie Starego Miasta, bulwarów nad Odrą (Bollwerk), decyzja o ich wyburzeniu oraz dalsza socjalistyczna i modernistyczna przebudowa miasta odsunęła miasto od rzeki i portu.

6. Port w całości przejęty został przez polskie władze z rąk sowieckich 19 września 1947 roku. Zasadnicze prace związane z odbudową portu prowadzone były w ramach tzw. planu trzyletniego w latach 1947-1949. W efekcie zdolność przeładunkowa portu zwiększyła się z 98 tys. t/rok (obrót w ruchu morskim wyniósł ok. 45 tys. t) w 1946 roku do 5,9 mln t/rok w 1959 roku.

7. W 1994 roku w porcie szczecińskim został ustanowiony wolny obszar celny. Działalność eksploatacyjna została podjęta 1 lipca 1995 roku na obszarze o powierzchni 4,49 ha. W 2000 roku poszerzono wolny obszar celny do 19 ha, a następnie w 2005 roku do 19,66 ha. W pierwszych dekadach XXI wieku w porcie przeprowadzono wiele inwestycji związanych z dostępem drogowym, estakad i wjazdów do portu. Obecnie port Szczecin zajmuje w swoich graniach 901 ha powierzchni lądowej, 2/3 terenów należy do Skarbu Państwa, pozostałe to miasta Szczecin i innych podmiotów (więcej: Palmowski, Bocheński, 2015; Zarząd Morskich Portów..., 2021).

Najnowsze informacje pochodzące z publikacji Zarząd Morskich Portów... (2021) świadczą o podjętych decyzjach dotyczących obecnych i przyszłych procesów inwestycyjnych. Przeprowadzana jest modernizacja drobnicowej części portu. Inwestycja docelowo obejmie budowę nowego nabrzeża Norweskiego - przedłużenie nabrzeża Fińskiego, pełniącego funkcję terminala kontenerowego. Remontowane będą istniejące nabrzeża Czeskie i Słowackie. Zaplanowano też budowę nabrzeża na długości ok. 600 m, które w przyszłości ma nazywać się nabrzeżem Duńskim. Poszerzony zostanie także Kanał Dębicki (ze 120 m do 200 m), który prowadzi do wspomnianych nabrzeży. Zaplanowano podobne prace w rejonie Basenu Kaszubskiego, Dąbrowieckiego, przebudowę istniejących nabrzeży (Katowickiego, Chorzowskiego i uskoków Gliwickiego i Chorzowskiego) na łącznej długości ok. 1300 metrów, obudowę brzegów wysp Ostrów Mieleński i Mieleńska. Zaletą obecnego układu portu w Szczecinie jest duże zaplecze terenów inwestycyjnych, które są oddalone od obszaru miasta w kierunku wysp obszaru Międzyodrza.

Uwolnione od działalności portowej i przemysłowej obszary na terenie Łasztowni, ponad 100 ha z Wyspą Grodzką, są elementem toczącej się od wielu lat w Szczecinie publicznej debaty pod hasłem powrotu miasta nad wodę. Nazwa terenu pochodzi od 
dawnej jednostki miary materiałów sypkich - łasztu i łacińskiego słowa „lastadie” oznaczającego ładunek. W ramach idei powrotu nad wodę stworzona została w 2007 roku strategia marketingowa Szczecina Stettin 2050 Floating Garden, w której znaczące miejsce ma połączenie potencjału przyrodniczego wynikającego $\mathrm{z}$ nadwodnego położenia z planowaną nowoczesną architekturą.

W wyniku działań wojennych i zniszczenia portu oraz terenów starego miasta przez naloty alianckie, dywersję niemiecką i grabieże sowieckie, odbudowy w myśl modernistycznych rozwiązań infrastrukturalnych (Trasa Nadodrzańska i Zamkowa) braku rekonstrukcji starej tkanki miejskiej (rozbiórka Starego Miasta) Szczecin „oddalił się" od wody. Opisane wyżej uwarunkowania rozwoju działalności portowej sprawiły, że tereny na wyspie Łasztownia (Kępa Parnicka, Wyspa Grodzka) oraz w okolicach byłej Stoczni Szczecińskiej przy ul. Kolumba nabrały cech zdegradowanych terenów poprzemysłowych i portowych - fotografia 1. W 2009 oraz 2011 roku obszar Międzyodrza i Łasztowni objęto miejscowym planem zagospodarowania przestrzennego.

W ustaleniach ogólnych w MPZP omawiany obszar przeznaczono na śródmiejską zabudowę wielofunkcyjną o charakterze centrotwórczym, z przestrzeniami publicznymi, m.in. nadwodnymi, o wysokim standardzie i szerokim spektrum usług, ze szczególnym uwzględnieniem usług publicznych, o znaczeniu ponadlokalnym. Wschodnią część tego obszaru, należącą do portu wolnocłowego, przeznaczonego na składy, przeładunek, usługi dystrybucyjno-logistyczne, przewiduje się sukcesywne przekształcać w struktury wielofunkcyjne, w tym wprowadzenie tam usług wystawienniczo-handlowych, hotelarstwa, rozrywki, sportu, turystyki, zespołów apartamentowych (obowiązujący plan miejscowy; Uchwała Nr XII/268/11..., 2011). Obszar objęty jest też programem rewitalizacji. Przedmiotem rewitalizacji są: budowa układu komunikacyjnego z przeprawami mostowymi, budowa infrastruktury technicznej, realizacja obiektów użyteczności publicznej, renowacja substancji budowlanej i zabytków, budowa przestrzeni publicznych wraz z wyposażeniem, w tym budowa/modernizacja nabrzeży dla jednostek pływających, tereny zieleni urządzonej, zagospodarowanie terenów na cele kultury, sportu, rekreacji i wypoczynku (Rada Miasta Szczecin, 2010).

Informacje zawarte $\mathrm{w}$ planie zagospodarowania przestrzennego przedstawiają ogrom problemów, jakie stwarza obszar poprzemysłowy i poportowy - rycina 9 i 10 .

Fotografia 1. Przykłady opuszczonych terenów portowych i poprzemysłowych w Szczecinie

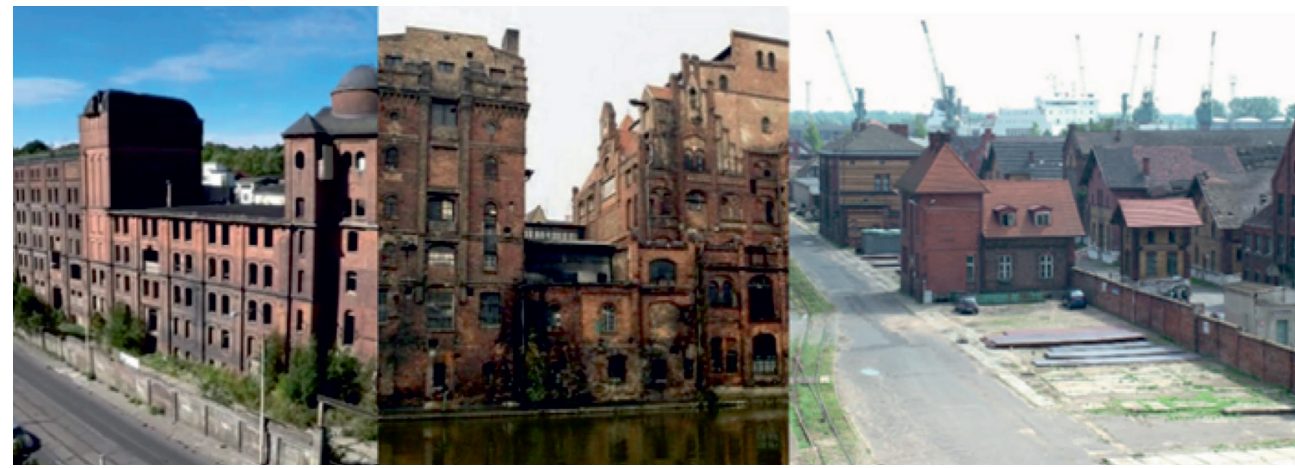

Źródło: prasa lokalna, fot. 3 J. Rudewicz 
Np. dużym problemem technicznym jest nośność gruntów, problemem prawnym występowanie wielu właścicieli działek i wymagania przepisów związanych z okalającymi opisywany obszar drogami wodnymi. Niełatwe jest pogodzenie współistnienia funkcji gospodarczych, rezydencjalnych, publicznych, skomunikowania obszaru, ochrony przyrody i krajobrazu oraz dziedzictwa i archeologii. Propozycje rewitalizacji Łasztowni pojawiły się także w Lokalnym Programie Rewitalizacji miasta z 2010 roku (aktualizowanym w 2017 roku). W rozdziale 4.1 „Kształtowanie struktury przestrzennej miasta” mówi się o wzmacnianiu tradycyjnej roli śródmieścia Szczecina, jako centrum miasta i ośrodka administracyjno-usługowego dla całego obszaru metropolitalnego, z ukierunkowaniem dalszego jego rozwoju w stronę Odry i wysp odrzańskich. Rejony wysp Międzyodrza i Stare Miasto to tereny inwestycyjne dla nowych struktur śródmieścia Szczecina, z preferencją dla jednostek prestiżowych o najwyższej randze, wysokich walorach estetycznych i użytkowych, ponadlokalnych funkcjach usługowych, biurowych, administracyjnych, turystycznych, powiązane z wysokostandardową funkcją mieszkalną i rewitalizacją istniejącej zabudowy historycznej. Opisywany obszar poportowy i poprzemysłowy poddany jest obecnie procesowi inwestycyjnemu. Zmodernizowaniu i uatrakcyjnieniu poddane zostały nadodrzańskie bulwary, stając się miejscem spacerowym z ofertą gastronomiczną oraz infrastrukturą umożliwiającą cumowanie jednostek pływających (przyłącza). Co cztery lata Szczecin jest gospodarzem finału międzynarodowych regat The Tall Ships Races, do miasta przypływa kilkadziesiąt dużych żaglowców i setki mniejszych jednostek. Jest to kilkudniowe wydarzenie masowe, które odbywa się sprawnie dzięki powstałej infrastrukturze.

Przykładem konwersji do nowej funkcji w strefie interface jest m.in. budynek dawnej rzeźni (nazwany Stara Rzeźnia). Po roku 1945 użytkowany był jako baza żywca

Rycina 9. Szczecin, granice miasta i tereny portowe oraz przemysłowe. Port w granicach lądowych liczy 901 ha, w tym powierzchnia składowa: odkryta 74 ha, kryta 12,5 ha. Dł. nabrzeży eksploatacyjnych wynosi $15 \mathrm{~km}$

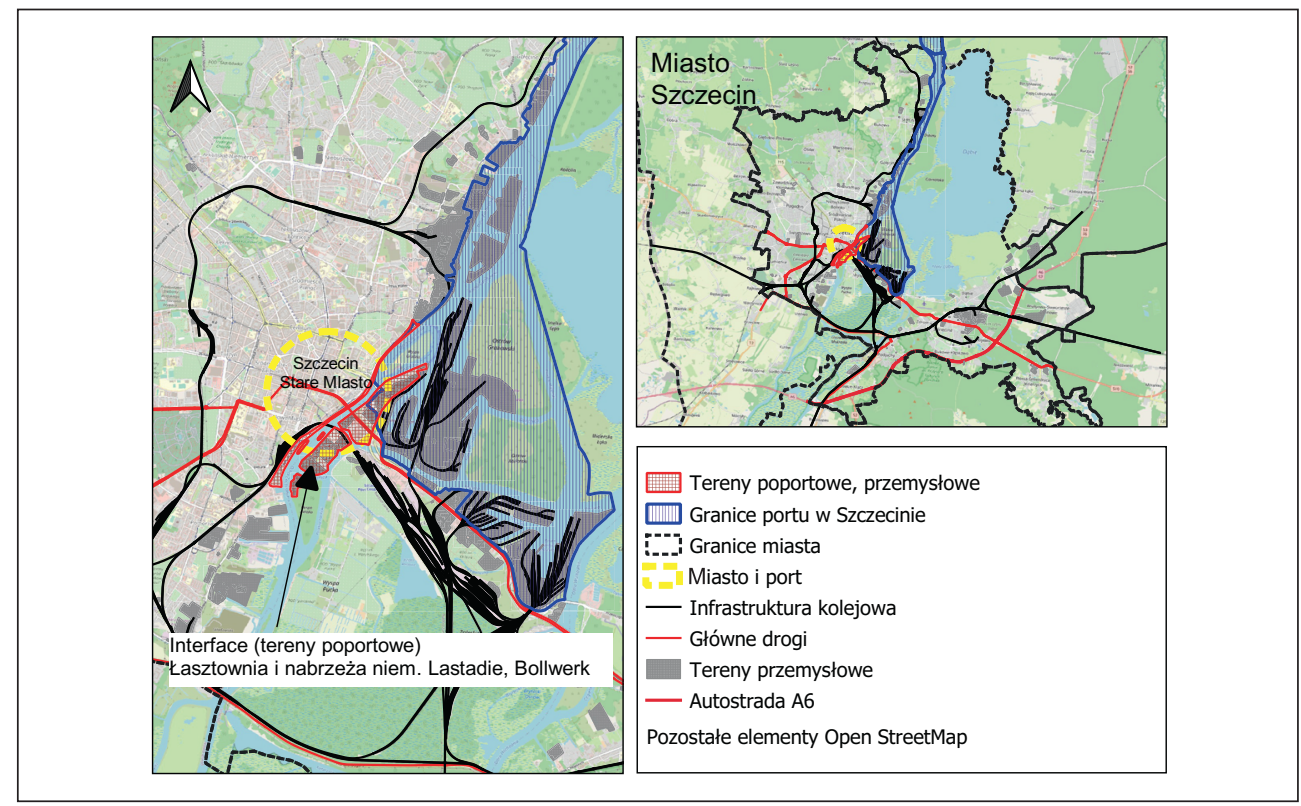

Źródło: opracowanie własne. Dane Misterstwa Gospodarki Morskiej i Żeglugi Śródlądowej 
Rycina 10. Plan sytuacyjny z rzutem lotniczym. Dawne tereny portowe i poprzemysłowe w Szczecinie, część obszaru Łasztowni i Międzyodrzaha
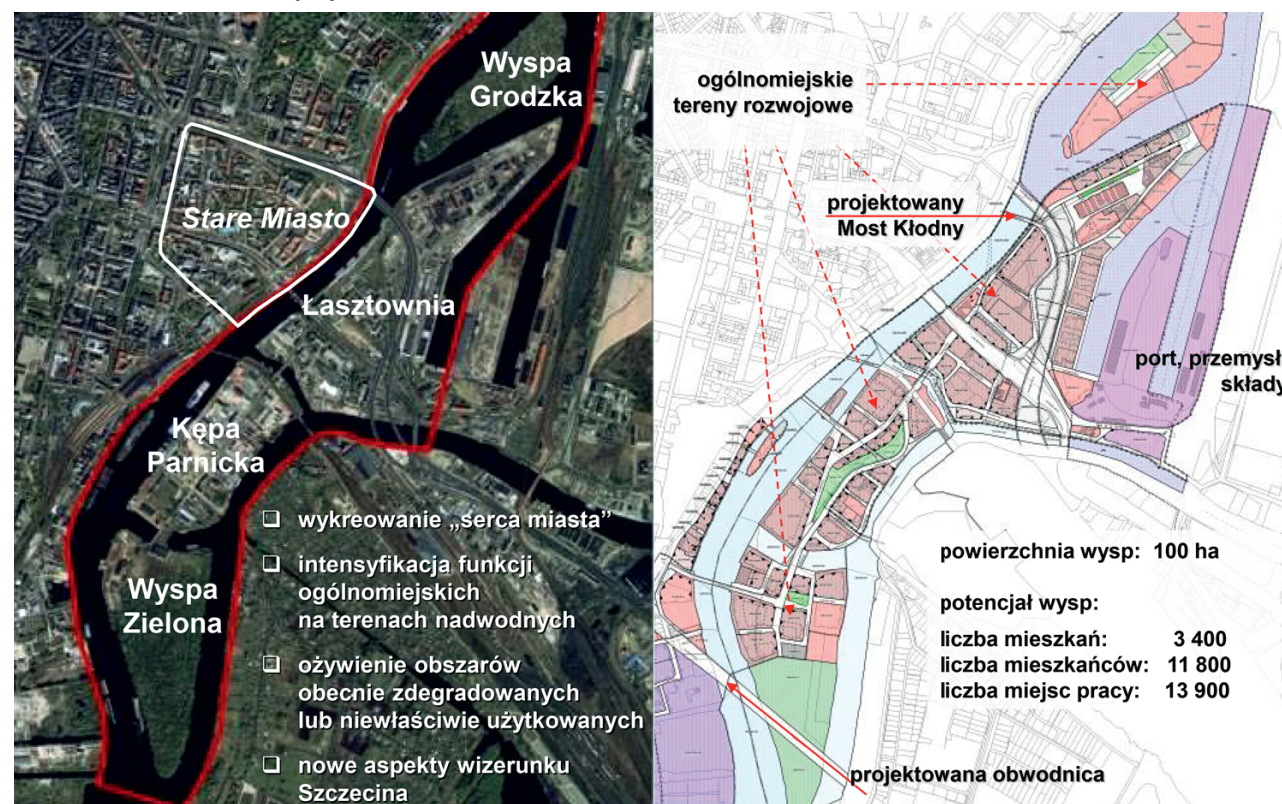

Źródło: Studium Uwarunkowań i Kierunków Zagospodarowania Przestrzennego Szczecina (2012)

wołowego dla zakładów mięsnych, a w latach 80. XX wieku pełnił rolę magazynu. Budynek jest nową siedzibą spółki CSL, która wyremontowała obiekt. W XIX-wiecznym budynku, niegdyś zaniedbanym i opustoszałym, po renowacji organizuje się wydarzenia kulturalne, prowadzona jest restauracja, sala konferencyjno-projekcyjna, księgarnia, galeria z kącikiem dla dzieci. Przykładem nowo powstałej inwestycji na trenach portowych jest otwarty w 2015 roku port jachtowy wraz z nowoczesnym zapleczem i mostem. To obiekt odwołujący się do tradycji morskich Szczecina. Część wyspy Grodzkiej, przy której znajduje się marina, pełni rolę plaży miejskiej, znajduje się tam klub i obszar pokryty piaskiem służący za miejsce uprawiania sportu i rekreacji. W rejonie Łasztowni budowany jest obecnie futurystyczny budynek Morskiego Centrum Nauki, który kształtem przypomina kadłub statku. Mieścić będzie planetarium i interaktywne wystawy poświęcone nauce i technice. Symbolem zmian na tych terenach, zdobywającym miano kolejnego fotogenicznego i ikonicznego obiektu, są pozostawione i odnowione przedwojenne żurawie portowe (firmy Krupp). Maszyny zostały podświetlone barwną iluminacją, która wzmacniana odbiciem w wodzie stanowi fotograficzną atrakcję. $\mathrm{Na}$ omawianym terenie powstał okazały biurowiec Lastadia, w jego południowej części rozpoczęto budowę osiedli mieszkaniowych, których głównym atutem ma być położenie nad wodą i walory widokowe. Wolne przestrzenie Łasztowni wykorzystywane są na różnego rodzaju wydarzenia kulturalne i miejsce dla parku rozrywki.

Stowarzyszenie Architektów Polskich wraz z władzami miasta ogłosiło w 2017 roku międzynarodowy konkurs na opracowanie koncepcji urbanistycznej dla obszaru Łasztowni pt. Szczecin: Łasztownia - nowe serce miasta. Do konkursu zgłosiły się 242 pracownie m.in. z USA i Japonii. Prace przysłało 26 zespołów. Pierwszą nagrodę otrzymało biuro Maćków Pracownia Projektowa, drugą zespół PAREGA, a trzecią pracownia 
architektek, Aleksandry Krzywańskiej i Mai Matuszewskiej. Zwycięska koncepcja zakłada śmiałe przesunięcie strefy rewitalizacji w stronę portu i zagospodarowanie terenów portu wolnocłowego przy zachowaniu zabytkowych budynków industrialnych, likwidację Trasy Zamkowej oraz uzupełnienie istniejących budynków o nowoczesną architekturę. W śmiałej koncepcji dużą wagę przywiązano do terenów zieleni oraz komunikacji pieszej (Architektura Murator, 2017; Gołębiewski, 2016). Koncepcja nie będzie realizowana w stu procentach. Przez Łasztownię poprowadzony będzie Nowy Most Kłodny wraz z układem komunikacyjnym, finalizowana jest budowa Morskiego Centrum Nauki. Problemem dla pełnej realizacji koncepcji mogą być rosnące potrzeby komunikacyjne miasta, które uwidaczniają się w krzyżowaniu się dróg i natężeniu ruchu, warunkiem płynności jest rozbudowa dróg obwodowych.

\section{WNIOSKI}

Miasto Szczecin rozwinęło się jako polifunkcyjna jednostka osadnicza. Port, będący w przeszłości integralną częścią miasta, w obecnych uwarunkowaniach technicznych, prawnych, ekologicznych i ekonomicznych stanowi w granicach administracyjnych obszar odrębny. Port jako czynnik miastotwórczy i inicjujący zaznaczył swój wpływ na tkankę miejską w przeszłości pozostawiając w niej liczne obiekty poportowe i poprzemysłowe w otoczeniu terenów nadwodnych. Port w Szczecinie jest obecnie uniwersalno-specjalistycznym portem morsko-rzecznym dla ładunków drobnicowych i masowych. Obsługuje linie żeglugowe bliskiego i średniego zasięgu oraz tranzyt, wraz z portem w Świnoujściu tworzy integralny zespół portów. Zaprezentowane w treści artykułu plany inwestycyjne i rozbudowująca się baza logistyczna portu koncentruje się głównie na obszarach już zainwestowanych lub nowych terenach. Rozwój gospodarczy zaplecza portu, a tym samym masa i wartość przeładunków wpływa na wzrost jego znaczenia na mapie gospodarczej kraju, sprzyja to integracji portu i miasta z sieciami transportowymi. Pod tym względem port ma charakter miastotwórczy, stanowiąc nadal dla części mieszkańców bezpośrednie i pośrednie miejsce pracy. Miastotwórczy charakter mają również tereny nadwodne interface i waterfront dające obecnie miastom portowym możliwość budowy obiektów usługowych i kulturalnych oraz rekreacyjnych (mariny, promenady nabrzeża, bulwary). Obszary te nie charakteryzuje już produkcja, lecz postindustrialna konsumpcja „entertainment machine”, która powinna odbywać się z zachowaniem industrialnego dziedzictwa materialnego. Włodarze miasta starają się przekształcać będące $\mathrm{w}$ ich gestii tereny nadwodne zgodnie z trendami wytyczonymi w miastach zachodnich. Takie działanie ma dwie wzmacniające się perspektywy. Pierwsza - wewnętrzna - poprawiająca i uatrakcyjniająca miasto dla jego mieszkańców, druga - wzmacniająca efekt wizerunkowy zewnętrzny - podkreślający portowy charakter miasta, uatrakcyjniający je wizualnie i nadający indywidualności. W Szczecinie, pomimo wielu sukcesów, wątpliwości budzi tempo przekształceń, pomijając ograniczenia kapitałowe, brak jest spójnej wizji obszaru Łasztowni i innych terenów, a dotychczasowe dokumenty planistyczne i strategiczne zawierają jedynie zarys kierunków zmian. Koncepcje urbanistyczne niestety nie stanowią realizowanego krok po kroku planu działań, pojawia się zagrożenie działań doraźnych. Przekształcenia przestrzenno-funkcjonalne Łasztowni wymagają od aktorów tego procesu wyważenia kwestii partycypacji i inkluzji społecznej z próbą odgórnego podejmowania decyzji. Zagrożeniem dla całego procesu może być też gentryfikacja polegająca na wprowadzeniu 
na omawiane w artykule obszary zabudowy luksusowej, o ograniczonej dostępności dla mieszkańców w myśl znanego w Polsce pojęcia neoliberalnego urbanizmu. Takie symptomy pojawiają się w związku z rozpoczętymi budowami luksusowych osiedli mieszkaniowych na omawianych terenach. Z kolei nadanie części bulwarów nadodrzańskich charakteru publicznego - strefy swobodnego spożycia alkoholu - powoduje konflikt funkcji reprezentacyjnej tego miejsca. Problematyka wzajemnych relacji miasta i portu to obszerne zagadnienie badawcze, niniejszy artykuł tylko w pewnym stopniu jej dotyka. Relacje miasta i portu na podstawie przeglądu literatury warto badać nie tylko opisowo i poprzez obserwację, ale stosując wielowymiarowy aparat statystyczny, służący do określania przepływów pomiędzy miastem, a portem np. poziomu zatrudnienia w przemyśle i porcie oraz gospodarce morskiej w kontekście egzo/endgenicznej funkcji miasta. Wśród zagadnień ekonomicznych wskazać można problematykę określenia efektu mnożnikowego i lokalizacyjnego aktywności gospodarczej wywoływanego poprzez istnienie portu i gospodarki morskiej. Innym obszarem badań mogą być kwestie zarządzania procesem zmian w obszarach poportowych, partycypacji społecznej, zrównoważonego transportu, a także szeroko rozumianej analizy konfliktów na różnych płaszczyznach: przestrzennej, ekonomicznej, społecznej i środowiskowej. Badania relacji miasta i portu wpisać można w różne skale. Od konkretnego miejsca, przypadku, poziomu osiedla, całego miasta aż do regionu metropolitalnego.

\section{Literatura \\ References}

Architektura Murator. (2017). Szczecińska Łasztownia - wyniki konkursu. Pozyskano z https:// architektura.muratorplus.pl/projekty/szczecinska-lasztownia-wyniki-konkursu_8019. html (15.08.2021).

Bird, J. (1963). The Major Seaports of the United Kingdom. London: Hutchinson.

Borruey, R. (1992). Réinventer une ville-port? Le cas de Marseille. Cahiers de la Recherche Architecturale, 30/31, 127-146.

Borruey, R., Fabre, M. (1992). Marseille et les nouvelles échelles de la ville portuaire. Annales de la Recherche Urbaine, 55/56, 53-62.

Brocard, M. (1994). Deux villes frontières portuaires. Le Havre et Southampton. La Revue d'Ici, $11,8-12$.

Cowan, D., Bunce, S. (2006). Competitive Cities and Secure Nations, Conflict and Convergence in Urban Waterfront. International Journal of Urban and Regional Research, 30(2), 427-439.

Ducruet, C. (2005). Approche comparée du développement des villes-ports à l'échelle mondiale. Problèmes théoriques et méthodologiques. Cahiers Scientifiques du Transport, 48, 59-79.

Ducruet, C. (2011). The port city in multidisciplinary analysis. W: J. Alemany, R. Bruttomesso (red.), La ciudad portuaria del siglo XXI. Nuevos desafíos en la relacíon puerto-ciudad $=$ The port city in the XXI century. New challenges in the relationship between port and city. Venezia: RETE, 32-48.

Forno, G. (1985). Gênes. Ville-port. Renaissance Urbaine en Europe. Etude, 27, 75-84.

Flis, J. (1985). Szkolny słownik geograficzny. Warszawa: WSiP.

Gołębiewski, J.I. (2016). Perspektywy rewitalizacji Międzyodrza w Szczecinie. Praca doktorska. Zachodniopomorski Uniwersytet Technologiczny w Szczecinie.

Gostomski, E., Nowosielski, T. (2021). Ewolucja i znaczenie portów morskich $w$ krajach Unii Europejskiej. Gdańsk: Wydawnictwo Uniwersytetu Gdańskiego.

Hayuth, Y. (1982). The port-urban interface. An area in transition. Arel, 4(3), 219-224.

Hoyle, B.S. (1988). Development dynamics at the port-city interface. W: B.S. Hoyle i in. (red.), Revitalising the Waterfront. International Dimensions of Dockland Redevelopment. London: Belhaven, 3-19.

Hoyle B.S. (1998). Cities and ports. Concepts and issues. Journal of Vegueta, 3, 263-278. 
Kotla, R. (2007). Z dziejów szczecińskiego portu. Magazyn Portowy ZMPSiŚ SA, 1.

Marcadon, J. (1997). La stratégie des armements maritimes et les métropoles portuaires. W: P. Claval, A.L., Sanguin (red.), Métropolisation et Politique. Paris: L'Harmattan, 189-203 (Collection 'Géographie et Culture).

Norcliffe, G., Basset, K., Hoare, T. (1996). The emergence of postmodernism on the urban waterfront. Journal of Transport Geography, 4(2), 123-134.

Notteboom, T. (1997). Concentration and load centre development in the European container port system. Journal of Transport Geography, 5(2), 99-115.

O'Connor, K. (1989). Australian ports, metropolitan areas and trade-related services. Australian Geographer, 20(2), 167-172.

Palmowski, T., Bocheński, T. (2015). Polskie porty morskie i rola kolei w ich obsłudze na przełomie XX i XXI wieku. Gdańsk; Pelplin: Wydawnictwo „Bernardinum”, 46-49 (Regiony nadmorskie; 23).

Palmowski, T., Pacuk, M., Michalski, T. (2001). Przemiany przestrzeni miejskiej miast portowych na przykładach Gdańska i Gdyni. W: Miasto postsocjalistyczne. Organizacja przestrzeni miejskiej i jej przemiany. XIV Konwersatorium wiedzy o mieście. Łódź: Łódzkie Towarzystwo Naukowe.

Rada Miasta Szczecin. (2010). Lokalny Program Rewitalizacji dla Miasta Szczecin. Pozyskano z http://konsultuj.szczecin.pl/konsultacje/files/9CD543BAF70F4D37A35893B6EE94C6DD /002\%20na\%20BIP.pdf

Runge, S. (2018). Przeobrażenia funkcjonalno-przestrzenne miast tradycyjnego regionu społeczno-ekonomicznego - wymiar teoretyczny. Studia Miejskie, 32, 21-33.

Seassaro, L. (1992). Gênes, ou le poids de la longue durée culturelle. Annales de la Recherche Urbaine, 55/56, 10-21.

Studium Uwarunkowań i Kierunków Zagospodarowania Przestrzennego Szczecina. (2012). Uchwała Nr XVII/470/12 Rady Miasta Szczecin z dnia 26 marca 2012 r. Pozyskano z http:// bip.um.szczecin.pl/chapter_11398.asp (dostęp 5.11.2021).

Uchwała Nr XII/268/11 Rady Miasta Szczecin z dnia 24 października 2011 r. Dziennik Urzędowy Województwa Zachodniopomorskiego Nr 134 poz. 2418.

Vigarié, A. (1979). Ports de commerce et vie littorale. Paris: Hachette.

Zaremba, P. (1962). Urbanistyka miast portowych. Szczecin: Szczecińskie Towarzystwo Naukowe.

Zarząd Morskich Portów Szczecin i Świnoujście S.A. (2021, 4 kwietnia). Historia Portów. Pozyskano z https://www.port.szczecin.pl/pl/porty/historia/\#

Żyszkowska, W., Spallek, W., Borowicz, D. (2012). Kartografia tematyczna. Warszawa: PWN.

Jacek Rudewicz, dr inż., Uniwersytet Szczeciński, Wydział Ekonomii Finansów i Zarządzania, Instytut Gospodarki Przestrzennej i Geografii Społeczno-Ekonomicznej. Ukończył kierunki: geografia ze specjalnością geografia społeczno-ekonomiczna, zarządzanie i marketing oraz ekonomia. W pracy naukowej zajmuje się m.in.: studiami miejskimi, rozwojem zrównoważonym, rozwojem regionalnym, geografią społeczno-ekonomiczną.

Jacek Rudewicz, PhD Eng. University of Szczecin, Faculty of Economics, Finance and Management, Institute of Spatial Management and Socio-Economic Geography. He graduated from Geography with a specialisation in socio-economic geography, management and marketing and economics. In his research work he deals with urban studies, sustainable development, regional and local development.

ORCID: https://orcid.org/0000-0002-2659-4754

\section{Adres/address:}

Uniwersytet Szczeciński

Wydział Ekonomii Finansów i Zarządzania

Instytut Gospodarki Przestrzennej i Geografii Społeczno-Ekonomicznej

ul. Mickiewicza 64

71-101 Szczecin, Polska

e-mail: jacek.rudewicz@usz.edu.pl 